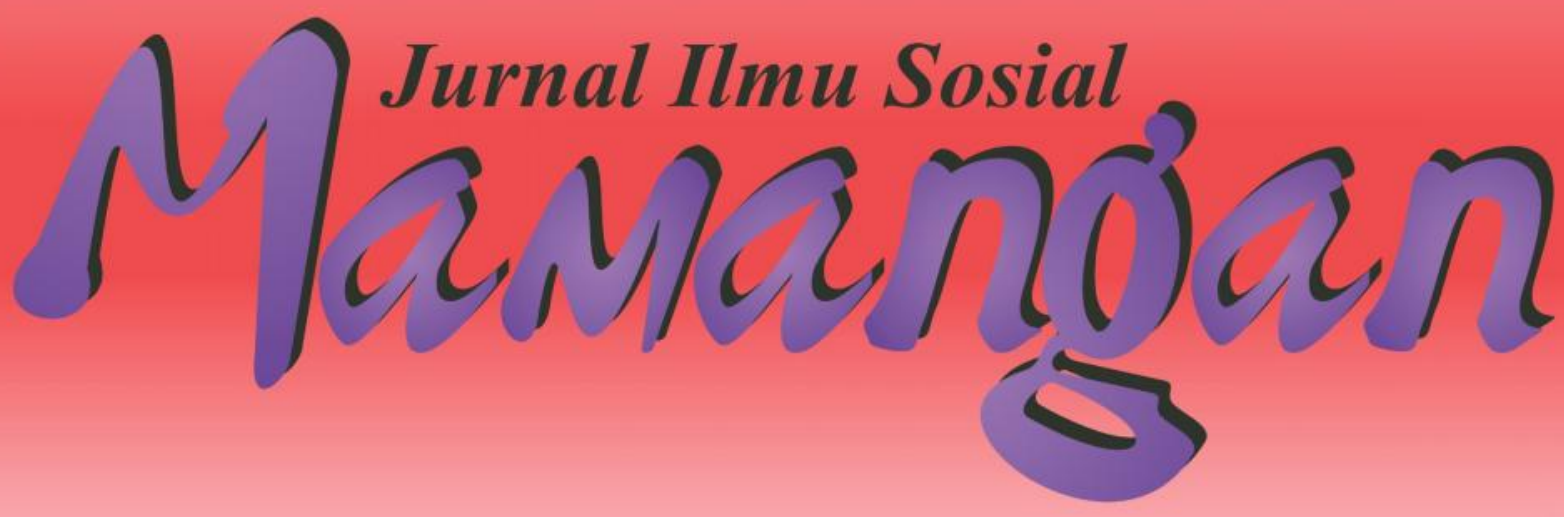

Diamika Perempuan Pedagang Makanan Di Sicincin

Elsa melia Roza, Yulkardi \& Rinel Fitlayeni

Motivasi \& Strategi Keluarga Miskin Nagari Talu, Kab. Pasaman Barat Melanjutkan Pendidikan Anak Ke Perguruan Tinggi

Cici Rahma Sari, Elvawati \& Dian Kurnia Anggreta

Dampak Sosial Ekonomi Objek Wisata The Unique Park Waterboom Di Kota Sawahlunto

Lisa Desatria, Fachrina \& Faishal Yasin

Pandangan Rumah Tangga Sasaran (RTS) Terhadap Pelaksanaan Dana Bergulir PNPM-MP Di Kelurahan Balai Gadang, Kota Padang Elparianti, ArdiAbbas \& Elvawati

Kehidupan Waria Di Jorong Mandiangin, Kecamatan Kinali, Kabupaten Pasaman Barat

Susanki \& Dian Anggraini Oktavia

Fungsi Koperasi Serba Usaha Ekonomi Desa (KSU-ED) Terhadap Masyarakat Nagari Tabek Talang Babungo, Kabupaten Solok Yenti Welia, Witrianto \& Refni Yulia 


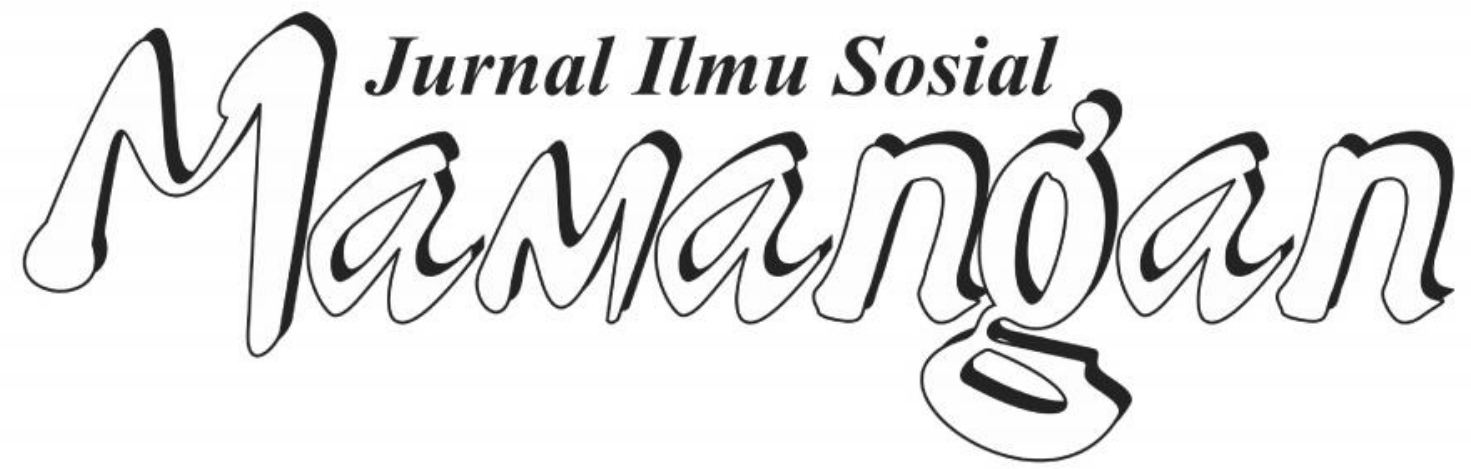




\section{Mitra Bestari}

Prof. Dr. Afrizal, MA. (FISIP, Unand Padang)

Dr. A. Latief Wiyata, M. Si. (Universitas Jember, Jember)

Prof. Dr. Badaruddin, M. Si. (FISIP, USU Medan)

Dr. Fikarwin Zuska, M. Si. (FISIP, USU Medan)

Nurus Shalihin, M. Si., Ph.D. (Fak. Ushuluddin IAIN Imam Bonjol Padang)

Dr. Semiarto A. Purwanto, M. Si. (FISIP, UI Jakarta)

Dr. Wahyu Wibowo, M. Si. (Universitas Nasional, Jakarta)

\section{Dewan Redaksi}

Dr. Zusmelia, M. Si.

Dr. Maihasni, M. Si.

Adiyalmon, S. Ag., M. Pd.

Firdaus, S. Sos., M. Si.

\section{Pemimpin Redaksi}

Firdaus, S. Sos., M. Si.

\section{Anggota Redaksi}

Dian Kurnia Anggreta, S. Sos., M. Si.

Rinel Fitlayeni, S. Sos., MA.

Surya Prahara, SH.

ISSN: 2301-8496

\section{Alamat Redaksi:}

Laboratorium Program Studi Pendidikan Sosiologi, STKIP PGRI Padang

Jl. Gunung Pangilun, Padang

Email: redaksimamangan@yahoo.com

Penerbit :

Program Studi Pendidikan Sosiologi, STKIP PGRI Padang

\section{Contac person :}

Firdaus (Hp. 085263881221/Email : daus gila@yahoo.com) 


\section{DAFTAR ISI}

Diamika Perempuan Pedagang Makanan Di Sicincin

Elsa melia Roza, Yulkardi \& Rinel Fitlayeni.

Motivasi \& Strategi Keluarga Miskin Nagari Talu, Kab. Pasaman Barat Melanjutkan Pendidikan Anak Ke Perguruan Tinggi

Cici Rahma Sari, Elvawati \& Dian Kurnia Anggreta.

Dampak Sosial Ekonomi Objek Wisata The Unique Park Waterboom Di Kota Sawahlunto

Lisa Desatria, Fachrina \& Faishal Yasin

Pandangan Rumah Tangga Sasaran (RTS) Terhadap Pelaksanaan Dana Bergulir PNPM-MP Di Kelurahan Balai Gadang, Kota Padang

Elparianti, Ardi Abbas \& Elvawati

Kehidupan Waria Di Jorong Mandiangin, Kecamatan Kinali, Kabupaten Pasaman Barat

Susanki \& Dian Anggraini Oktavia

Fungsi Koperasi Serba Usaha Ekonomi Desa (KSU-ED) Terhadap Masyarakat Nagari Tabek Talang Babungo, Kabupaten Solok 


\title{
FUNGSI KOPERASI SERBA USAHA EKONOMI DESA (KSU-ED) TERHADAP MASYARAKAT NAGARI TABEK TALANG BABUNGO, KABUPATEN SOLOK
}

\author{
1Yenti Welia, ${ }^{2}$ Witrianto, ${ }^{3}$ Refni Yulia \\ ${ }^{1 \& 2}$ Sekolah Tinggi Keguruan dan Ilmu Pendidikan (STKIP) PGRI Sumatera Barat \\ ${ }^{2}$ Universitas Negeri Padang
}

\begin{abstract}
Many efforts to improve the economy of the community, either by building it Rural Economy Business Multipurpose Cooperative (KSU-ED). Nagari Talang Babungo to improve the economy of the community and establish cooperative KSU-ED. After the founding of KSU-ED economy and the welfare of society is increasing, because the cooperative has helped to lend capital to improve the business community, and various efforts have been developed to improve the business community. KSU-ED Tabek have increasing from year to year, as evidenced by SHU (Business Profits) increasing so does the number of its members, and co-operatives are very active role in improving the local economy. The establishment of good cooperative impact people's lives, especially the members and its own management, its impacts, among others in the social and economic spheres of society.
\end{abstract}

Keywords: Cooperation, Socio-Economic, Society

\begin{abstract}
ABSTRAK
Berbagai upaya meningkatkan perekonomian masyarakat salah satunya dengan mendirikannya Koperasi Serba Usaha Ekonomi Desa (KSU-ED). Nagari Talang Babungo untuk meningkatkan perekonomian masyarakat dan koperasi mendirikan KSU-ED. Setelah berdirinya KSU-ED perekonomian dan kesejahteraan hidup masyarakat semakin meningkat, karena koperasi telah membantu meminjamkan modal untuk meningkatkan usaha masyarakat, dan berbagai macam usaha telah dikembangkan untuk meningkatkan usaha masyarakat. Perkembangan KSU-ED Tabek dari tahun ketahun semakin meningkat, terbukti dengan SHU (Sisa Hasil Usaha) yang semakin meningkat begitu juga dengan jumlah anggotanya, serta koperasi sangat berperan aktif dalam meningkatkan ekonomi masyarakat. Berdirinya koperasi membawa dampak baik bagi kehidupan masyarakat khususnya para anggota dan pengurusnya sendiri, dampak yang ditimbulkannya antara lain dalam bidang sosial dan ekonomi masyarakat.
\end{abstract}

Kata Kunci: Koperasi, Ekonomi, Masyarakat

Jurnal Ilmu Sosial Mamangan, Volume II Nomor 2, juli-Desempber 2013 | 108 


\section{PENDAHULUAN}

Koperasi adalah badan usaha yang beranggotakan orang per orang atau badan berlandaskan asas kekeluargaan dan demokrasi ekonomi. Koperasi juga merupakan kumpulan orang-orang yang bekerjasama memenuhi satu atau lebih kebutuhan ekonomi atau bekerjasama melakukan usaha dengan tujuan untuk meningkatkan taraf hidup dan kesejahteraan anggota-anggotanya. Koperasi bersifat terbuka untuk umum dimana setiap orang tanpa memandang golongan, aliran, kepercayaan atau agama orang itu dapat diterima sebagai anggota koperasi (Widiyanti 1988).

Banyak perkembangan dan kemajuan yang terjadi pada saat sekarang khususnya dalam bidang ekonomi. Namun, bagi rakyat kecil masih merasa kesulitan dalam melakukan upaya untuk mengembangkan dirinya agar mendapatkan kesejahteraan dan penghidupan yang layak. Masyarakat kecil atau ekonomi lemah juga memiliki keinginan berkembang, namun tidak memiliki kemampuan, sumber daya seperti keahlian ,modal materi, jaringan untuk membuka usaha produktif. Permasalahan tersebut dirasakan oleh masyarakat Nagari Talang Babungo, dalam upayanya mengembangkan ekonomi mereka mengalami kendala dalam bidang permodalan. Masyarakat Talang Babungo yang masyarakatnya $70 \%$ petani padi dan palawija sangat membutuhkan modal yang sangat besar dalam pengembangan usaha mereka.

Untuk menyikapi persoalan di atas sulit bagi rakyat kecil untuk berupaya secara sendiri-sendiri ditengah persaingan usaha yang ketat dan mayoritas dikuasai para pemodal besar. Oleh karena itu, diperlukan usaha sekuat tenaga untuk membangun sebuah kerjasama, bersatu, dan saling menguatkan dengan cara mendirikan sebuah koperasi. Koperasi memiliki prisip, sumber daya dari anggota, dikerjakan oleh anggota dan hasilnya dinikmati oleh para anggota secara adil dan kekeluargaan. Salah satu upaya yang dilakukan oleh pemerintah maupun masyarakat dalam memecahkan permasalahan perekonomian yang dialami oleh masyarakat dalam memenuhi kebutuhan hidupnya adalah dengan mendirikan koperasi. Koperasi ini diharapkan dapat membantu masyarakat dalam mengatasi permasalahan ekonomi yang dihadapi oleh masyarakat.

Program koperasi yang menonjol pada masa ini adalah pembentukan Koperasi Unit Desa (KUD). Pengertian KUD disini adalah suatu koperasi serba usaha yang beranggotakan penduduk desa dan berlokasi didaerah pedesaan, daerah kerjanya biasanya mencakup satu wilayah kecamatan. Pembentukan KUD ini merupakan penyatuan dari beberapa koperasi pertanian yang kecil dan banyak jumlahnya dipedesaan. Selain itu KUD memang secara resmi didorong perkembangan oleh pemerintah.

Begitu juga halnya di Nagari Talang Babungo Kecamatan Hiliran Gumanti Kabupaten Solok, dalam upaya mengatasi permasalahan perekonomian yang dihadapi oleh masyarakat Talang Babungo timbul suatu inisiatif/keinginan oleh pemerintah dan masyarakat setempat untuk mendirikan sebuah koperasi. Koperasi tersebut diberi nama koperasi serba usaha ekonomi Desa Tabek (KSU-ED), dimana Koperasi Serba Usaha ini adalah koperasi koperasi yang kegiatan usahanya di berbagai ekonomi yang tidak hanya berfungsi pada satu bidang usaha saja tapi banyak usaha atau fungsi dalam meningkatkan kesejahteraan dan perekonomian masyarakat. Berdirinya Koperasi Serba Usaha Ekonomi Desa Tabek ini tidak terlepas dari keinginan pemerintah dan masyarakat Talang Babungo sendiri dalam meningkatkan ekonomi serta dalam memenuhi kebutuhan hidup mereka.

Koperasi Serba Usaha Ekonomi Desa Tabek (KSU-ED) tabek ini merupakan sebuah koperasi yang tergolong kedalam sebuah koperasi primer. Yaitu sebuah koperasi yang 
anggotanya terdiri dari individu-individu, dan KSU-ED Tabek juga merupakan sebuah koperasi yang tergolong kedalam Multiple purpose cooperative atau koperasi serba usaha, yaitu koperasi yang lapangan usahanya bermacam-macam (Zein 1985).

Koperasi yang ada di Nagari Talang Babungo Kecamatan Hiliran Gumanti Kabupaten Solok ini berbeda dengan koperasi-koperasi yang ada di daerah lain pada umumnya, KSU-ED Tabek ini bukan hanya sekedar koperasi simpan pinjam serperti kebanyakan koperasi yang ada di Kabupaten Solok. KSU-ED Tabek ini juga melakukan usaha-usaha atau kegiatan lainnya seperti: Unit Simpan Pinjam Bulanan (BBM), Unit Penyewaan Pelaminan, Unit Jasa Penggemukan Sapi, Unit Penampungan Hasil Panen Petani dan Penggilingan Hasil Panen Petani dalam meningkatkan hasil dan mengembangkan perekonomian masyarakat Nagari Talang Babungo Kabupaten Solok.

Membicarakan masalah kehidupan ekonomi suatu kelompok masyarakat, maka pembicaraan tidak akan lepas dari masalah yang berkaitan dengan kehidupan sosial, seperti halnya taraf hidup masyarakat. Kesejahteraan masyarakat nagari Talang Babungo akan dapat dicapai salah satunya dengan mendirikan koperasi KSU-ED tersebut dan dengan adanya penyaluran dana dari koperasi itu sendiri walaupun cicilannya dilakukan satu kali seminggu.

Untuk dapat memberikan pinjaman atau kredit Koperasi memerlukan modal, yang mana Modal Koperasi yang utama adalah simpanan anggota sendiri dari uang simpanan yang dikumpulkan bersama-sama kemudian diberikan pinjaman, dengan pinjaman seorang petani dapat membeli pupuk, benih unggul, dan alat-alat lainnya, begitu juga dengan palawija sehingga hal demikian dapat membantu meningkatkan hasil usaha taninya. Hal tersebut juga berarti membantu menaikkan pendapatanya. Dilihat dari kandisi bangunan rumah, sekarang sudah banyak rumah mereka yang permanen bila dibanding dengan dahulunya yang masih semi permanen, dari segi pendidikan yang dulunya banyak anak yang putus sekolah, yang hanya tamat SD, SMP, namun sekarang dengan adanya koperasi pendidikan anakanak mereka tidak terputus lagi, bahkan sudah banyak yang melanjutkan ketingkat yang lebih tinggi.

Berdirinya Koperasi Serba Usaha Ekonomi Desa (KSU-ED) Tabek dapat membantu meningkatkan perekonomian masyarakat Nagari Talang Babungo yang mata pencaharian masyarakat $70 \%$ petani. Koperasi dapat memberikan modal serta berbagai wadah penampungan hasil pertanian masyarakat, sehingga tidak terjadi adanya penekanan harga yang berlebihan oleh para agen.

\section{TINJAUAN PUSTAKA}

Penelitian ini juga didasari oleh beberapa penelitian yang sudah pernah dilakukan. Pertama penelitian yang dilakukan oleh Sulasmi pada tahun 2006 dengan judul penelitian; koperasi tenaga kerja bongkat muat di pelabuhan teluk bayur padang tahun 1989-2007 (Sulasmi 2006). Penelitian ini menggambarkan dampak berdirinya koperasi (KOPERPAM) bagi anggota bongkar muat di pelabuhan teluk bayur. Hasil penelitian ini adalah berdirinya koperasi ini memberikan dampak perkembangan ekonomi anggota koperasi. Penelitian kedua dilakukan oleh Hikmalyati pada tahun 2001. Penelitian dengan judul koperasi mahasiswa IKIP Padang sejak berdirinya pada tahun 1984-1999 dilakukan di padang. Penelitian ini menghasilkan adanyaupaya koperasi untuk kesejahteraan anggotanya senyan menjaga eksistensi koperasi (Hikmalyati 2001). Penelitian ketiga dilakukan oleh Rinal Zulrahmi pada tahun 2005 dengan judul Dinamika Kperasi Industri Perabot di Kambang Hilir. Penelitian ini fokus pada perkembangan koperasi industri dengan bidang usaha perabot. Penelitian ini menghasilkan adanya 
perkembangan usaha perabot akibat adanya koperasi usaha Industri perabot (Zulharmi 2005).

Pada umumnya penelitian yang ada di Sumatera Barat masih melihat koperasi berdasarkan undang-undang perkoperasian. Tipe koperasi diminan adalah koperasi serba usaha. Koperasi serba usaha adalah koperasi yang kegiatan usahanya di berbagai segi ekonomi yang tidak hanya berfungsi pada satu badan usaha saja tapi banyak usaha atau fungsi dalam meningkatkan kesejahteraan dan perekonomian masyarakat. Menurut James pengertian petani adalah orang yang bercocok tanam (melakukan budidaya) di lahan pertanian. Petani adaah sebutan bagi mereka yang menyelenggarakan usaha tani, dan petani juga dapat diartikan sebagai orang yang menggantungkan hidupnya pada lahan pertanian sebagai mata pencaharian utamanya.

Masyarakat desa adalah kesatuan hidup manusia yang berinteraksi menurut suatu sistem adat istiadat dalam pemanfaatan lahan atau tanah oleh penduduk atau masyarakat yang bersifat serta memiliki rasa solidaritas yang tinggi dalam kehidupan untuk mencapai suatu kesatuan yang utuh. Masyarakat desa juga diartikan sebagai masyarakat yang jauh dari pusat pemerintahan dari sstem mata pencahariannya tidak terlalu berfariasi (Soekanto 2012).

Berbagai jenis koperasi lahir seirama dengan aneka jenis usaha untuk memperbaiki kehidupan, secara garis besar jenis koperasi yang ada dapat dibagi menjadi 5 golongan yaitu, (1) Koperasi Konsumsi adalah barang yang diperlukan setiap hari, misalnya: barang-barang pangan, barangbarang sandang dan barang pembantu keperluan sehari-hari, oleh karena itu koperasi yang mengusahakan kebutuhan sehari-hari disebut Koperasi Konsumsi. (2) Koperasi kredit atau simpan pinjam, dimana koperasi kridit didirikan untuk memberikan kesempatan kepada anggota-anggotanya memperoleh pinjaman dengan mudah dan dengan ongkos (bunga) yang ringan. Itulah sebabnya koperasi ini disebut dengan koperasi kredit. (3) Koperasi Produksi yaitu Koperasi yang bergerak dalam bidang produk pembuatan dan penjulan barangbarang baik yang membentuk sebagai organisasi maupun orang-orang anggota diluar organisasi. (4) Koperasi jasa adalah koperasi yang berusaha dibidang penyedian jasa tertentu bagi para anggota maupun masyarakat umum, contohnya adalah koperasi angkutan, Koperasi Perencanaan dan konstruksi Bangunan, Koperasi Asuransi Indonesia, dan lain-lain. (5) Koperasi Serba Usaha/Koperasi Unit Desa (KUD) adalah suatu Koperasi serba usaha yang beranggotakan penduduk desa dan berlokasikan didaerah pedesaan yang selalu ada penyediaan dan menyalurkan saranasarana produksi seperti sarana sebelum dan sesudah panen dan jasa-jasa lain (Pandji 1998).

Koperasi yang ada di Nagari Talang Babungo Kecamatan Hiliran Gumanti Kabupaten Solok in merupakan Koperasi yag termasuk kepada Koperasi kredit atau Koperasi Simpan Pinjam dan Koperasi Serba Usaha, karena Koperasi KSU-ED Tabek tersebut disamping melakukan simpanpinjam juga memiliki berbagai macam progam usaha untuk meningkatkan kesejahteraan dan perekonomian masyarakat.

\section{METODE PENELITIAN}

Metode yang digunakan dalam penelitian ini adalah metode sejarah. Untuk mendapatkan data yang relevan dengan permasalahan ini digunakan teknik-teknik penelitian sesuai dengan ketentuanketentuan dalam penulisan sejarah. Ada empat tahap dalam penulisan ini yaitu: heuristik, kritik sumber, interpretasi, analisis dan terakhir adalah Historiografi atau penulisan (Sjamsuddin 2007). 
Adapun langkah-langkahnya yaitu yang pertama heuristik atau mengumpulkan data dari dua sumber yaitu sumber primer dan sekunder. Sumber primer berupa arsip didapat dari data KSU-ED Tabek itu sendiri dan wawancara dengan pengurus KSU-ED, sedangkan data Sekunder diperoleh melalui studi literatur dan wawancara. Studi literatur ini dilakukan dengan melakukan penelitian pustaka dan kearsipan. Studi kearsipan diambil dari KSU-ED Tabek Kenagarian Talang Babungo Kecamatan Hiliran Gumanti Kabupaten Solok, dan lainlain. Sedangkan wawancara dilakukan dengan mewawancarai ketua, anggota dari KSU-ED Tabek Nagari Talang Babungo Kecamatan Hiliran Gumanti Kabupaten Solok, dan berbagai pihak yang berperan penting dalam perkembangan lembaga tersebut.

Kedua kritik sumber, merupakan tahap pengolahan data atau menganalisis sumber baik internal maupun eksternal. Kritik eksternal dilakukan dengan cara mencek keaslian sumber serta memilih mana yang lebih relevan dengan kajian penelitian tersebut. Kritik internal adalah kritik yang dilakuakan untuk menguji kebenaran atau keaslian isi sumber dengan meminta pendapat informan lainnya. Ketiga, interpretasi yaitu proses menginterpretasikan fakta-fakta yang diperoleh sesuai dengan konteks peristiwa dan zamannya, menggabungkan, mengelompokkan data-data yang sama serta membandingkan dan menghubungkan berbagai jenis data yang telah teruji kebenaran dan kesesuaiannya. Langkah terakhir dalam metode sejarah, adalah historiografi yaitu proses menyalin fakta, data yang telah diseleksi dengan cara memilah-milah data, menggabungkan, mengelompokan serta menghubungakan berbagai jenis data sehingga diperoleh butir-butir informasi yang dibutuhkan dan kemudian dirangkai dalam bentuk sebuah tulisan ilmiah dengan kaidah yang berlaku dalam ilmu sejarah.

\section{LATAR BELAKANG KSU-ED TABEK}

Berdirinya KSU-ED Tabek tidak terlepas dari faktor perekonomian yang dialami oleh masyarakat Nagari Talang Babungo. Semakin melemahnya perekonomian masyarakat Nagari Talang Babungo dan semakin sulitnya masyarakat dalam memenuhi kebutuhan hidup, serta timbul berbagai kendala yang dihadapi dalam perkembangan usaha mereka menjadi suatu permasalahan yang serius dalam kehidupan masayarakat Nagari Talang Babungo.

Berbagai usaha telah dilakukan oleh masyarakat Nagari Talang Babungo dalam memecahkan masalah ekonomi yang dialami namun belum dapat mengatasinya. Kesulitan dalam pengembangan ekonomi yang dirasakan oleh para pemuka masayarakat Nagari Talang Babungo berserta masyarakat untuk mendirikan sebuah lembaga perekonomian yang dapat menyokong perkembangan ekonomi masayarakat Nagari Talang Babungo. Untuk mengembangkan perekonomiannya mereka melakukan usaha bersama dan akhirnya timbul suatu gagasan untuk membentuk koperasi. Koperasi yang didirikan di Nagari Talang Babungo tersebut diberi nama dengan Koperasi Serba Usaha Ekonomi Desa (KSU-ED) Tabek, yang mana KSU-ED ini adalah koperasi yang kegiatan usahanya di berbagai segi ekonomi yang tidak hanya berfungsi pada satu badan usaha saja tapi banyak usaha atau fungsi dalam meningkatkan kesejateraan dan perekonomian masyarakat.

Selain faktor di atas, faktor berdirinya KSU-ED Tabek karena belum adanya lembaga keuangan yang berdiri di Nagari Talang Babungo. Tidak adanya lembaga keuangan seperti Bank, KUD, maupun KSUD tentu mempersulit masyarakat dalam pengembangan usahanya. Dengan demikian timbul suatu inisiatif dari candiak pandai, masyarakat, serta pemuka adat Nagari 
Talang Babungo untuk mendirikan sebuah lembaga keuangan yang diberi nama KSU-ED Tabek. Awal berdirinya koperasi ini bermula dengan dibentuknya PKK yaitu pembinaan kesejahteraan keluarga dengan jumlah anggota sebanyak 30 orang yang terbentuk pada tahun 1992, dan pada tahun 2003 koperasi tersebut diganti nama KSU-ED Tabek.

Berdirinya koperasi ini tentu diharapkan dapat membantu masyarakat Nagari Talang Babungo dalam mengatasi permasalahan perekonomian yang mereka hadapi, Nagari Talang Babungo yang sebagian besar bermata pencaharian petani dan pedagang tentu membutuhkan modal dalam mengembangkan usaha mereka. Oleh karena itu masyarakat Nagari Talang Babungo membentuk koperasi sebagai wadah penunjang perekonomiannya, juga semangat yang tinggi sampai sekarang KSUED masih bisa eksis dan mampu bertahan dengan perkembangan yang cukup baik, hal ini tentu saja tidak terlepas dari partisipasi yang tinggi antar anggota dengan pengelolanya, selain itu rasa kebersamaan itulah yang mampu menjadikan koperasi berjalan lancar. Koperasi yang berazaskan kekeluargaan ini dan tidak memberikan bunga yang besar kepada anggotanya dapat memberikan dampak yang positif bagi anggotanya.

\section{PERANAN KSU-ED TABEK DALAM MENINGKATKAN PEREKONOMIAN MASYARAKAT}

Peran koperasi sebagai lembaga ekonomi rakyat sudah dapat dilihat secara nyata. Koperasi di kenagarian Nagari Talang Babungo telah berhasil menghimpun anggotanya untuk memperjuangkan peningkatan pendapatan, perbaikan kehidupan dengan berhimpun dan membuat perencanaan pengembangan usaha besrsama. Sebagai lembaga koperasi telah mampu menyerap tenaga kerja meskipun dalam ratio kecil tapi dengan hal ini juga membantu perekonomian masyarakat.

KSU-ED Tabek yang ada di Nagari Talang Babungoberperan aktif dalam membangun dan meningkatkan perekonomian masyarakat, khususnya perekonomian anggota koperasi tersebut. Selain itu KSU-ED Tabek juga berperan aktif dalam meningkatkan kesejahteraan ekonomi dan sosial anggotanya. Semenjak berdiri sampai sekarang KSU-ED Tabek selalu menunjukkan peranannya dalam perkembangan perekonomian masyarakat Nagari Talang Babungo. Adapun peranan yang ditunjukan dalam perekonomian masyarakat Nagari Talang Babungo yaitu:

Pertama tahun 2003-2006 membantu masyarakat dalam permasalahan permodalan dalam pengembangan usaha mereka, yang mana semulanya para masyarakat sangat sulit mengembangkan perekonomian dan usaha mereka walaupun ada beberapa para tengkulak yang bersedia memberikan modal kepada masyarakat yang membutuhkan. Tetapi para tengkulak tersebut memberikan bunga yang sangat besar terhadap pinjaman yang diberikan serta setiap masyarakat yang minjam modal usaha harus menjual hasil usahanya kepada para tengkulak tersebut sesuai harga yang mereka tetapkan, sehingga hal tersebut manambah permasalahan baru dalam perkembangan perekonomian Nagari Talang Babungo. KSU-ED Tabek selain membantu masyarakat dalam permasalahan modal juga membantu masyarakat agar tidak terikat dan berkaitan dengan para tengkulak-tengkulak yang mencari keuntungan sendiri. Selain itu KSU-ED Tabek juga memberikan keringanan dalam masalah prosedur dan memberikan bunga yang ringan kepada setiap anggota koperasi. Ketika ini telah dilakukan oleh KUD-ED, anggota koperasi lebih mengutamakan menggunakan koperasi untuk solusi permodalan usaha mereka.

Kedua tahun 2007-2011 membentuk sebuah kegiatan yang bertujuan untuk 
membantu masyarakat dalam meningkatkan perekonomian. Usaha tersebut adalah menampung dan membantu anggota KSU-ED Tabek dalam memasarkandan menjualkan hasil produksi para anggota KSU-ED Tabek, serta menyediakan alat dalam penggolahan hasil produksi anggota koperasi seperti kilangan tebu dan membantu masyarakat dalam mencari informasi tentang harga terbaru sesuai harga pasar. Upaya uang dilakukan oleh koperasi ini sangat membantu melepas keterikatan petani dengan tengkulak. Ini merupakan lanjutan dari program simpan pinjam yang sudah dilaksanakan untuk membantu permodalan anggota. Kemudian masalah yang ditemui anggota adalah upaya pemasaran hasil tani yang masih berhubungan dengan tengkulak. Tengkulak sesama tengkulak memiliki strategi bersama untuk menekan harga hasil tani, yang mengakibatkan harga jual tetap rendah. Hal ini disadari oleh petani sehingga mereka mengupayakan koperasi bisa juga sebagai penampung hasil tani dan menjualnya ke luar daerah. Keuntungan yang di dapat koperasi akan menjadi aset bersama oleh anggota sehingga anggota koperasi secara otomatis mendapat manfaat dari Sisa Hasil Usaha (SHU) koperasi pada tiap tahunnya.

\section{DAMPAK KSU-ED TABEK TERHADAP MASYARAKAT NAGARI TALANG BABUNGO}

\section{BIDANG SOSIAL}

Pertama Tahun 2003-2006 KSU-ED memberikan dampak dalam kehidupan sosial masyarakat menciptakan terwujudnya kehidupan masyarakat damai dan tentram, karena dulu sebelum koperasi ini berdiri masyarakat kurang tentram disebabkan perekonomian yang lemah, untuk meminjam modal saja kepada orang lain sulit. Namun setelah koperasi ini berdiri masyarakat untuk meminjam modal sangat mudah. Di samping terwujudnya masyarakat yang tentram koperasi ini mendorong terwujudnya aturan yang manusiawi yang dibangun tidak di atas hubunganhubungan kebendaan tetapi di atas rasa kekeluargaan. Dengan tujuan agar tidak adanya rasa persaingan antara yang satu dengan yang lainnya, karena kalu mengutamakan kebendaan potensi menimbulkan perpecahan lebih tinggi. Selain dampak diatas koperasi juga memiliki dampak mendidik anggotanya untuk memiliki semangat kerjasama dan semangat kekeluargaan dengan berusaha untuk tidak membedakan-bedakan antara yang satu dengan yang lain dan membuka usaha untuk anggotanya.

Kedua Tahun 2007-2011 dampak dari KSU-ED berperan mengembangkan dana sosial yang mana di keluarkan dana sosial seperti: masing-masing jorong di berikan dana sumbangan untuk perbaikan jalan, membantu biaya pernikahan, kematian, uangnya berasal dari sisa hasil usaha (SHU).

\section{BIDANG EKONOMI}

$\begin{array}{ccr}\text { Pertama } & \text { Tahun } & \text { 2003-2006 } \\ \text { dampaknya } & \text { masyarakat } & \text { mudah }\end{array}$ mendapatkan modal untuk usaha, jadi masyarakat tidak perlu lagi berurusan dengan rentenir. Selain itu masyarakat dapat memperoleh barang-barang kebutuhan pokok dengan harga miring (murah). Kedua Tahun 2007-2011 dampaknya memudahkan masyarakat yang mata pencahariannya petani untuk mendapatkan pupuk, mesin kilangan tebu dan kebutuhan tani lainnya.

\section{KESIMPULAN}

Koperasi Serba Usaha Ekonomi Desa (KSU-ED) Tabek merupakan sebuah wadah atau lembaga yang sangat berfungsi membantu meningkatkan perekonomian dan kesejahteraan masyarakat Nagari Talang Babungo, yang awalnya masyarakat sulit untuk meminjam modal, dengan melakukan pinjaman kepada rentenir sekarang masyarakat bisa melakukan peminjaman ke koperasi. 
Perkembangan KSU-ED dari tahunketahun meningkat baik itu dari segi usaha yang dikembangkan maupun dari segi peningkatan anggotanya serta perolehan sisa hasil (SHU) yang mereka peroleh setiap tahunnya. KSU-ED sangat berperan aktif dalam meningkatkan ekonomi masyarakat khususnya bagi anggotanya, mempertinggi taraf hidup dan tingkat kecerdasan masyarakat, serta sebagai wadah atau tempat penimbangan ekonomi masyarakat Talang babungo

Seiring dengan kehadiran koperasi menimbulkan berbagai dampak masyarakt khususnya anggota dari koperasi tersebut. Dampak yang di timbulkan ada di bidang sosial dan ekonomi, bidang sosial seperti terwujudnya masyarakat damai, mendidik anggota untuk memiliki semangat kerjasama, memberikan bantuan kepada anak yatim, sedangkan bidang ekonomi seperti: dapat meningkatkan penghasilan anggota, menumbuhkan sikap jujurdan terbuka serta masih banyak keungtungan yang mereka peroleh dari KSU-ED Tabek tersebut.
DAFTAR PUSTAKA

Hikmalyati. 2001. "Koperasi Mahasiswa IKIP Padang 1944-1999.” Universitas Negri Padang.

Pandji, Anoraga Dkk. 1998. Dinamika Koperasi. Padang: Rineka Cipta.

Sjamsuddin, Herlius. 2007. Metodologi Penelitian Sejarah. Yogyakarta: Penerbit Ombak.

Soekanto, Soerjono. 2012. Sosiologi Suatu Pengantar. Jakarta: PT Raja Grafindo Persada.

Sulasmi, Mimi. 2006. “Koperasi Tenaga Kerja Bongkar Muat Di Pelabuhan Teluk Bayur Padang 1989-2007." Sekolah Tinggi Keguruan dan Ilmu Pendidikan PGRI Sumatera Barat.

Widiyanti, Ninik dan Sunindhia. 1988. Koperasi Dan Perekonomian Indonesia. Jakarta: Rineka Cipta.

Zein, Abbas. 1985. Koperasi Indonesia Suatu Pengantar. Padang: UNP Press.

Zulharmi, Rinal. 2005. "Dinamika Koperasi Industri Perabot Kamang Hilir; Suatu Tinjauan Historis (1973-1992)." Universitas Negri Padang. 
